\title{
The Study of User Perception Towards Digital Information Design
}

\author{
Afdallyna Fathiyah Harun ${ }^{1}$, Nurfarahhanis Abdul Rasid ${ }^{2}$, Saiful Izwan Suliman ${ }^{3}$, Natrah \\ Abdullah ${ }^{4}$, Ismail Musirin ${ }^{5}$ \\ ${ }^{1,2,4}$ Faculty of Computer and Mathematical Sciences, Universiti Technologi MARA, 40450 Shah Alam, Selangor \\ Darul Ehsan, Malaysia \\ ${ }^{3,5}$ Faculty of Electrical Engineering, Universiti Technologi MARA, 40450 Shah Alam, Selangor Darul Ehsan, \\ Malaysia
}

Article History: Received: 11 January 2021; Accepted: 27 February 2021; Published online: 5 April 2021

\begin{abstract}
Social media is increasingly becoming a key platform in disseminating information to the masses. With its free platform and wide audience penetration, various topics are shared across which also includes promoting environmental awareness. However, just like various other topics, any digital information constantly competes for user attention and consumption. The information design strategy put in place must be understood to assess user perception towards the content where a well-designed information will motivate users to like and share content. A study employing Instagram post-type categorization and survey probing user perception was carried out in the context of NGOs championing recycling efforts. The findings show that users prefer visualized information. The results can be used as a guideline for digital information designers to improve the information design technique particularly in the context of creating awareness that could potentially dive into virality element fitting with user perception and preferences.
\end{abstract}

Keywords: Human Information Interaction; Human Computer Interaction; User Experience; Digital Information Design; Social Media.

\section{Introduction}

The advent of social media started in the early days of the Internet, where people began to exchange information and interact with one another. As technology evolves, networks have been built where everyone can use the technologies without much problem. In fact, ninety percent of all online users use social media in some way or the other. The advancement of Social Web 2.0 has also allowed users to interact with not only friends and families but also with activities, community groups and other organizations. Enabling people to connect to friends and the community at large allows them to receive updates [1].

Users have various motivations in using the Internet for networking such as social interaction and interacting with other people with similar interest, to be updated with the latest news, information seeking, communication facilitation and sharing information with others [2]. There are well over 200 social networking sites that cater to the needs of a wide range of people differentiated by language and geographical location [3]. The fastest growing section of the internet is the social networking sites such as Facebook, Instagram, Twitter, and Snapchat, among others. While the popularity of these social networking sites varies according to the functionality, the Instagram platform is found as the more preferred medium for businesses to reach out to their target audience [4]. The appealing factor largely lies on the population of over 1 billion users in Instagram (Instagram, 2018). It was also found that about $90 \%$ of the Instagram users follows business accounts (Instagram, 2019) making it a lucrative and freely available networking opportunity not to be missed. Thus, Instagram is among the fastest growing social networks globally. More significantly, Instagram is a site that can produce the highest level of engagement with the user on posted content.

Part of the content that can be found in Instagram is information creating awareness among the public, with one example being the promotion and initiatives of recycling. Recycling is a procedure of collecting, sorting, and processing waste into new things or products [5]. If citizens commit to recycling, a lot of benefits can be gained financially and environmentally such as reduce resources and energy demand, reduce the need to convert more land into land-fill sites, reduce pollution and greenhouse gases, as well as able to protect natural habitat $[6,7]$. In 2018 alone Malaysia has produced about 3 million tonnes of waste and out of all the huge amount, only $0.06 \%$ or 1,800 tonnes of waste were recycled, and the remaining were sent to the landfills [8]. The solid waste management goal was to achieve a rate of $40 \%$ waste diversion from landfill and by 2020 the recycling rate should be $22 \%$ as mentioned in the Eleventh Malaysia Plan (2016 - 2020) [9]. Unfortunately, this is still a remote number to reach with Malaysia's recycling performance being relatively low compared to developed countries [9]. Nevertheless, effort towards recycling must persevere in an effort for a better future. It is believed that one way to achieve this is through persuasive digital information design.

Persuasion involves the conduct of attitude change to recipiency management involving interactive activity [10]. The lack of recycling is largely due to a person's apathetic attitude attributed to the lack of knowledge in 
environmental awareness $[11,12]$. They perceive recycling as complicated to do as they need to spend time and find it dirty to separate the trash mixed with food waste [12, 13]. Reception towards recycling can be managed through encouragement or mandatory means. The former is when citizens are presented with how recycling can facilitate self-satisfaction and better future generation while the latter is separation of household waste made obligatory as means to cultivate the recycling behaviour [7, 14]. The former is where interactive activity plays a significant role which can be mediated through social media. This is line with findings from [15] where citizens attested that receiving information from social media can motivate them to recycle.

Human Information Interaction is one area of computing which looks into how information can be communicated to the audience and one primary way to achieve this is by understanding user needs as well as making sure the information offers connection to the audience [16].

Our study has attempted to understand elements of digital information design in spreading the information throughout a wide network of consumers with inexpensive transmission, exponential referrals as well as promotions [17] within the context of encouraging citizens to recycle. We postulate that social network services (SNS) can easily spread the messages or information to promote the recycling behaviour [18] and able to share the content to the others. However, there is lack of understanding on how users perceive the recycling information on social media and if the digital information design fits with user preference.

The aim of this study is to categorize user perception towards recycling information in social networks. This was facilitated with a case study of two Non-Governmental Environmental Organization Instagram account on how they promote recycling through digital information design. We believe the outcome can serve as guidelines on digital information design techniques fitting with user perception and preferences. This would promote better Human Information Interaction and User Experience in turn encouraging reception to change.

\section{Methodology}

\section{Research Setup}

The context of this study is understanding user perception of digital information design that is applied in social media. We opted with recycling as the digital information topic design. Our research is motivated with two research questions: (i) what type of information are shared by the recycling society on Instagram page, and (ii) how users respond to the recycling posts on Instagram page. We began by selecting potential Instagram accounts as case study candidates. We used several filtering criteria which include:

A. Using "recycling" as our primary keyword search in the Instagram platform as this is the core focus of content analysis.

B. Focus on prominent Non-Governmental Environment Organization as we believe their standing would provide a sense of legitimacy in providing informative content to the public.

C. Active in posting entries as well as encouraging user response. This is to enable frequent and significant number of data collection.

D. Large number of followers as to gauge user reception to different content provided by the Instagram account owners.

This resulted into two Instagram accounts which are Greenpeace USA and Greenpeace Malaysia. Greenpeace is a Non-Governmental Environmental Organization founded in 1971. Its establishment is to campaign on environmental worldwide issues such as climate change, anti-nuclear, deforestation, recycling, and other environmental related issues. Greenpeace has often been described as the most visible environmental organization in the world due to their dedication in educating the public and influencing change in both private and public sector [19].

The selection of the two accounts enable information insight from both local and international perspectives. Greenpeace Malaysia is locally based while the opposite is for Greenpeace USA. Using both accounts as case study allowed us to gauge if there are any distinct differences or similarities in terms of digital information design in promoting recycling initiatives. Table 1 provides a summary of the selected accounts.

Table 1 Summary of Selected Instagram Account

\begin{tabular}{llll}
\hline $\begin{array}{l}\text { Instagram } \\
\text { Account }\end{array}$ & Handle Name & $\begin{array}{l}\text { Instagram } \\
\text { Est. Date }\end{array}$ & $\begin{array}{l}\text { No. of followers (at } \\
\text { time of study) }\end{array}$ \\
\hline $\begin{array}{l}\text { Greenpeace } \\
\text { Malaysia }\end{array}$ & @greenpeacemy & 15.12 .2015 & 16,700 \\
$\begin{array}{l}\text { Greenpeace } \\
\text { USA }\end{array}$ & @greenpeaceusa & 26.11 .2012 & 282,000 \\
\hline
\end{tabular}

Our study involved making observation of two (2) Instagram accounts from the period 1st January 2020 to 30 th of April 2020. One of the authors (referred to as FH for easy referencing), followed both Instagram accounts 
which enabled FH to be updated in her timeline. It must be noted that since Greenpeace also share posts on other environmental issues, only posts pertaining to recycling matters were recorded for our study's analysis. These posts were downloaded, compiled, and analysed after the data collection period ends. The elements that have been recorded for every post are the picture, caption, date of post, number of likes and hashtags used.

\section{Study A: Instagram Digital Information Design}

To understand digital information design preferred by users, we first categorised the posts downloaded from Greenpeace Malaysia and Greenpeace USA Instagram accounts. This was done at the end of data collection period which was May 2020. The structure design of the social media-based digital information was examined by adapting the post-type codes used by [20] which were "News", "Infographic", "Official Function" and "Random Posts" post-types. However, from the initial analysis it was found that some of the categories were not suitable and that other information patterns emerged. Following this, we refined the codes from [20] to better reflect the information design type that emerged from the analysis. Description of the codes is available in Table 2 .

Table 2 Instagram Post-Type Description

\begin{tabular}{ll}
\hline $\begin{array}{l}\text { Instagram } \\
\text { Post-Type }\end{array}$ & Description \\
\hline Infographic & $\begin{array}{l}\text { Data visualisations that used visual representation such as charts, } \\
\text { graphs, shapes, images, and a very minimal amount of text [21] to } \\
\text { deliver the ideas to the audiences about the tips or messages } \\
\text { regarding the recycling } \\
\text { A sentence, phrase, or passage from speech or text that someone } \\
\text { has said or written [22] as a form of motivation or persuasion to } \\
\text { change. }\end{array}$ \\
Events & $\begin{array}{l}\text { Information pertaining to events conducted by the society to invite } \\
\text { the public in joining community works or awareness activities. }\end{array}$ \\
& $\begin{array}{l}\text { The post generally contains pictures, dates, and location of the said } \\
\text { event }\end{array}$ \\
Animated & $\begin{array}{l}\text { Video, gif or any form of animated content to convey messages to } \\
\text { the users }\end{array}$ \\
\hline
\end{tabular}

At the time of this study, user response to an Instagram post can be in the form of 'Like', 'Comment' and 'Repost'. 'Like' involves clicking the heart icon to show favourable response while the 'Comment' feature enable users to react to the post using text or emojis. As the context of this study investigates user favourable perception towards the digital information shared by the Instagram account owner, we feel the number of 'Likes' best represents this. This is because, user often click 'Like' when they find it favourable to them.

\section{Study B: User Perception Interview}

We opted to understand user perception towards the Instagram posts through a series of brief interview with several Instagram users. We felt that simply relying on Instagram sourced data is insufficient to understand how user truly feel as perception relates to emotion and thoughts which are not quantifiable by simply means of "Like" at an Instagram post. Respondents were selected through an open invitation by FH in one of her Whatsapp group. Each of the respondents were briefed on the purpose of the interview.

The interview was done through WhatsApp call video as this study took place during worldwide movement control order (MCO) of which face to face interview session was not possible. The eligibility to participate is that respondents must have their own Instagram account and are experienced Instagram users. For the interview, respondents were presented with questions that probe their information preference. Respondents were also shown samples of post-types (as defined in Table 2) where their perception towards the post-types were elicited.

\section{Statistical Analysis}

Descriptive statistics were generated for each post-type where we calculated post-type frequency and the total number of likes. Qualitative analysis was done on the interview transcript to generate a theme of user reception towards the Instagram post-types. The core idea here is to demonstrate that digital information design significantly affects user favourable perception towards it.

\section{Results}

Information Design in Instagram Posts and 'Like' Reactions (Study A)

Throughout our study duration, a total of fifty-five posts which fits with the design criteria defined in Table 2 were collected from Greenpeace Malaysia (30 posts) and Greenpeace USA (25 posts).Table 3 summarises the 
post-type distribution of the collected posts. We found that Greenpeace Malaysia makes an average of 1 post per day with an average of 0.53 'infographics', 0.27 'quotes', 0.17 'events' and 0.03 'animated post'. Greenpeace USA makes an average of 0.83 posts per day with an average of 0.23 'infographics', 0.37 'quotes', 0.2 'events' and 0.03 'animated post'. From the results, both accounts approached information sharing differently with Greenpeace Malaysia posted more 'infographics' post-type while Greenpeace USA shared more 'quotes' posttype.

Table 3 Post-Type Distribution Summary

\begin{tabular}{|c|c|c|c|c|}
\hline \multicolumn{5}{|c|}{ Greenpeace Malaysia } \\
\hline Post Type & Month & & $\begin{array}{l}\text { Total } \\
\text { Post }\end{array}$ & $\begin{array}{l}\text { Likes for All } \\
\text { Post } \\
\text { Combined }\end{array}$ \\
\hline \multirow{5}{*}{ Infographic } & \multicolumn{2}{|l|}{ January } & 9 & 2222 \\
\hline & \multirow{3}{*}{\multicolumn{2}{|c|}{$\begin{array}{l}\text { February } \\
\text { March } \\
\text { April }\end{array}$}} & 2 & 1287 \\
\hline & & & 1 & 164 \\
\hline & & & 4 & 1153 \\
\hline & $\begin{array}{l}\text { Total } \\
\text { type }\end{array}$ & Post- & 16 & \\
\hline \multirow{5}{*}{ Quote } & \multicolumn{2}{|l|}{ January } & 4 & 917 \\
\hline & & 1 & 381 \\
\hline & \multicolumn{2}{|l|}{ March } & 2 & 545 \\
\hline & \multicolumn{2}{|l|}{ April } & 1 & 765 \\
\hline & $\begin{array}{l}\text { Total } \\
\text { type }\end{array}$ & Post- & 8 & \\
\hline \multirow{5}{*}{ Events } & \multicolumn{2}{|l|}{ January } & 1 & 324 \\
\hline & & 1 & 476 \\
\hline & \multicolumn{2}{|l|}{ March } & 1 & 469 \\
\hline & \multicolumn{2}{|l|}{ April } & 2 & 353 \\
\hline & $\begin{array}{l}\text { Total } \\
\text { type }\end{array}$ & Post- & 5 & \\
\hline \multirow{5}{*}{$\begin{array}{l}\text { Animated } \\
\text { post }\end{array}$} & \multicolumn{2}{|l|}{ January } & 0 & 0 \\
\hline & \multicolumn{2}{|l|}{ February } & 1 & 1620 \\
\hline & \multicolumn{2}{|l|}{ March } & 0 & 0 \\
\hline & \multicolumn{2}{|l|}{ April } & 0 & 0 \\
\hline & $\begin{array}{l}\text { Total } \\
\text { type }\end{array}$ & Post- & 1 & \\
\hline \multicolumn{5}{|c|}{ Greenpeace USA } \\
\hline Post Type & \multicolumn{2}{|l|}{ Month } & $\begin{array}{l}\text { Total } \\
\text { Post }\end{array}$ & $\begin{array}{l}\text { Likes for All } \\
\text { Post } \\
\text { Combined }\end{array}$ \\
\hline \multirow{5}{*}{ Infographic } & \multicolumn{2}{|l|}{ January } & 2 & 8707 \\
\hline & \multicolumn{2}{|l|}{ February } & 2 & 8480 \\
\hline & \multicolumn{2}{|l|}{ March } & 1 & 4567 \\
\hline & \multicolumn{2}{|l|}{ April } & 2 & 5509 \\
\hline & $\begin{array}{l}\text { Total } \\
\text { type }\end{array}$ & Post- & 7 & \\
\hline \multirow{5}{*}{ Quote } & January & & 3 & 7688 \\
\hline & February & & 3 & 10891 \\
\hline & March & & 4 & 10976 \\
\hline & April & & 1 & 13900 \\
\hline & $\begin{array}{l}\text { Total } \\
\text { type }\end{array}$ & Post- & 11 & \\
\hline & January & & 0 & 0 \\
\hline & February & & 2 & 4761 \\
\hline Fyents & March & & 0 & 0 \\
\hline Events & April & & 4 & 7152 \\
\hline & $\begin{array}{l}\text { Total } \\
\text { type }\end{array}$ & Post- & 6 & \\
\hline
\end{tabular}




\begin{tabular}{llll}
\hline & January & 0 & 0 \\
Animated & February & 1 & 1257 \\
post & March & 0 & 0 \\
& $\begin{array}{l}\text { April } \\
\text { Total Post- } \\
\text { type }\end{array}$ & 0 & 0 \\
& $\mathbf{1}$ & \\
\hline
\end{tabular}

There was a total of 94,564 post 'likes' (10,676 'likes' for Greenpeace Malaysia; 83,889 'likes' for Greenpeace USA). For both Instagram accounts, only 1 'animated post' post-type was posted and therefore was excluded from further analysis as it does not show any significant patterns of user reaction towards the post-type. For Greenpeace Malaysia, 'infographics' post-type received the greatest number of likes with 45.2\% 'Like' reaction from total likes. The least favoured post-type by users is 'events' post-type with an average of $15.19 \%$ 'Like' reaction from total likes. For Greenpeace USA, 'quotes' post-type received the greatest number of likes with $51.8 \%$ 'Like' reaction from total likes. The least favoured post-type by users is 'events' post-type with an average of $14.2 \%$ 'Like' reaction from total likes.

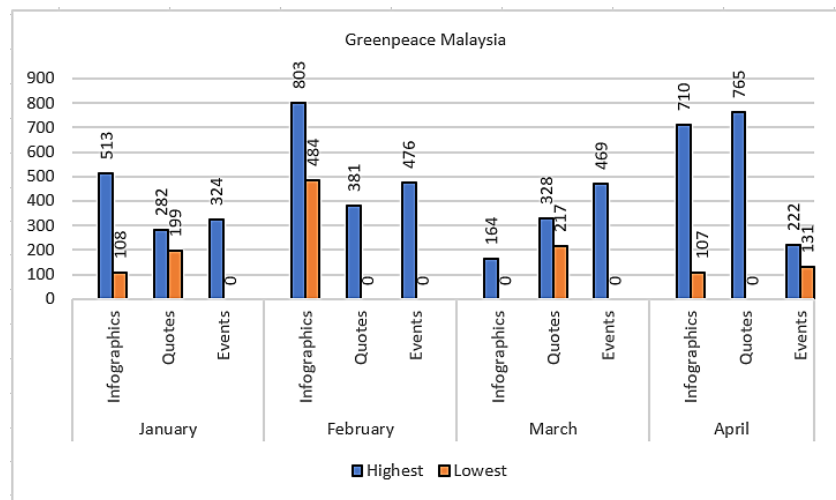

Figure 1 Post Type Reception for Greenpeace Malaysia Instagram Account

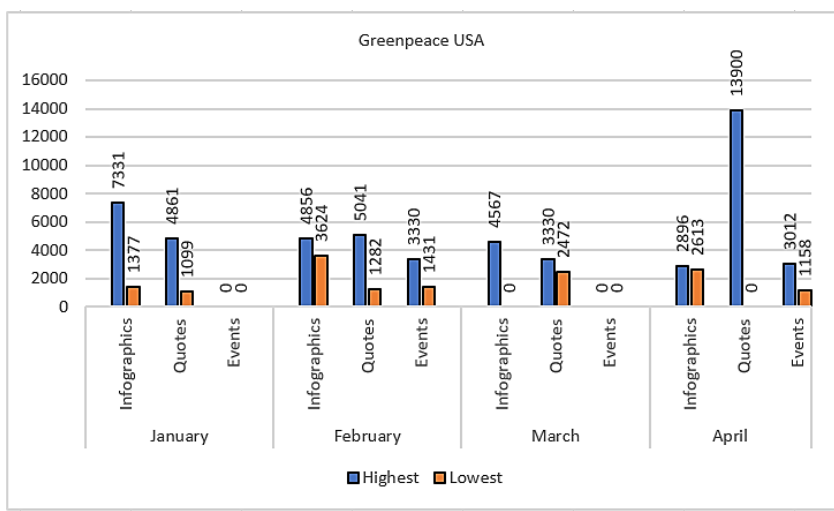

Figure 2 Post Type Reception for Greenpeace USA Instagram Account

Figure 1 and Figure 2 illustrates the most and least number of 'Likes' received for each post-type in every month of the study duration for both Instagram accounts. For Greenpeace Malaysia, 'infographics' post-type often received the most likes in most of the months followed with 'event's post-type. Surprisingly, 'quotes' post-type received the greatest number of likes in April even though only one such post-type was posted by the account. For Greenpeace USA, it appears that 'infographics' and 'quotes' post-type were well-liked by users with reception from users are often favourable. It also appears that 'quotes' post-type received the most 'likes' from users in April. It appears that audience for both Instagram accounts commonly prefer 'infographics' post-type. This is because, it often shows high recorded number of 'likes', where it was observed that even at the low side of like preference, the reception is still favourably better that other post-types.

Another important observation from Table 3, Figure 1 and Figure 2 is that different country relies on different type of information medium and audience reception also differs according to country. Greenpeace Malaysia mainly relies on 'infographics' post-type and this post-type consistently receives high number of 'like'. 
Greenpeace USA on the other hand relies on two post-types where it was found that 'infographics' and 'quotes' post-types are evenly posted every month and audience seems to favour both post-types in an almost equal manner.

Figure 3 illustrates the digital information design elements present in each post-type. All post-types make use of posters however the content of the visuals are different to reflect the nature of the post-type as well as intention of the posts.

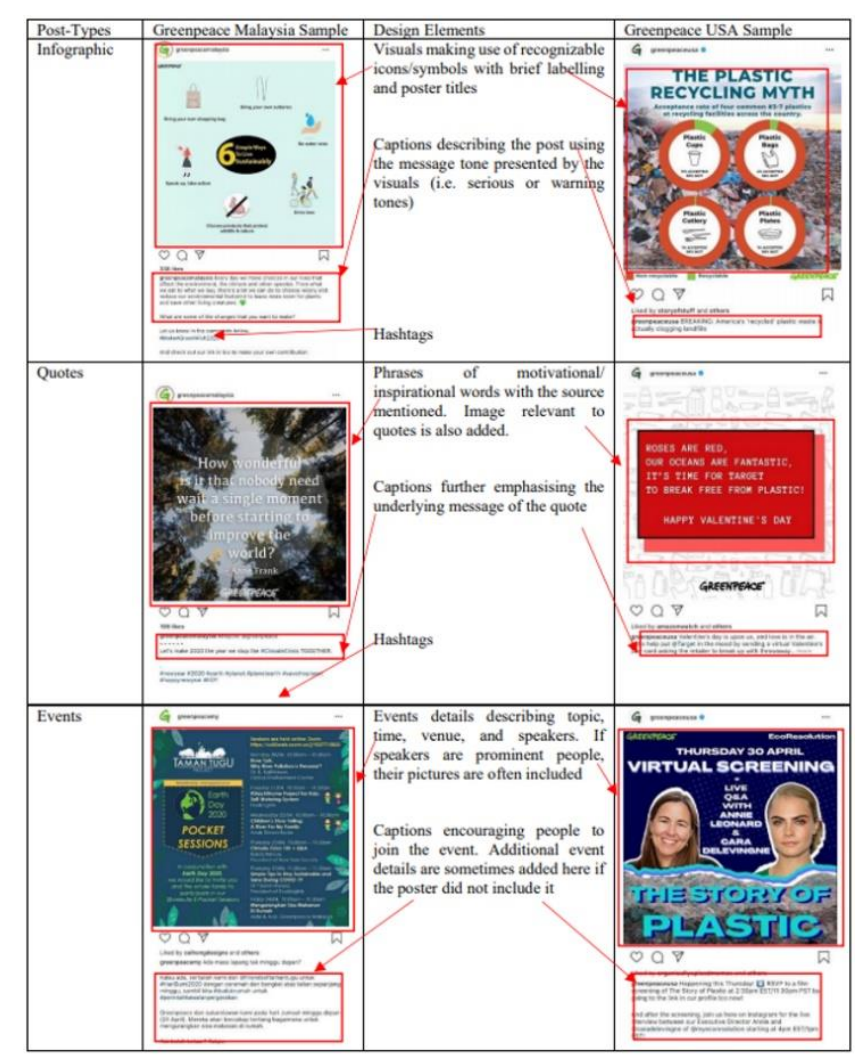

Figure 3 Design Elements of Each Post-Types

\section{User Perception towards Design Information Design (Study B)}

Five respondents were recruited for our interview with the age range of 25 to 30 years old. There are all Instagram users based in Malaysia. As part of the interview procedure, respondents were presented with samples of each post-types (as per Table 2) which receives the most and least number of likes for each of the month under study. However, respondents were not informed on the 'likes' reception to avoid bias. The samples were used simply to elicit their general impression of the posts and the reasoning to such impression. All of the posttype samples were shown using WhatsApp platform and not directly on the Instagram account as to avoid any elements of bias where respondents might be distracted by other content or influenced by the reception appearance in the Instagram account in the form of likes and number of comments.

The respondents find 'infographics' post-type easy to understand and less wordy. The visuals in infographics are found to be visually informative as it gives clear illustration on how users can engage in recycling process. One of the respondents commented that the use of visuals can convey more information than a text can while another respondent added that visual stories are more holistic. Respondents found the samples of 'quotes' post-type inspirational which can drive people towards achieving a sense of objective. The 'quotes' post-type appear appealing to users when it offers comfort, motivation and humour. But most importantly, they find it relatable when the quote supports the purpose of the organization which in this case, Greenpeace organization which promotes a better environment. Such digital information design of 'quotes' post-type is believed to be capable in driving more 'likes'.

On post-type samples with least number of 'likes', the respondents found that most of the information conveyed were confusing, have dull pictures and lack information 'interactivity'. Interactivity here refers to information which creates a nuance of 'communication' or ability for user to 'talk back' to the information albeit imaginatively which helps in information interpretation [23]. Moreover, they feel the hashtags used are also irrelevant to the information context. All these elements lead users to find the post lacklustre which may help us understand why such posts could have received lesser number of likes. 
During the interview process, we also sought to understand user needs when it comes to human information interaction in the form of digital information design. We learned that they prefer posts with less text [24] and simple captions. They claimed that they do not usually bother with lengthy captions as typical Instagram browsing usually involves scrolling the timeline and only stopping at a post that caught their attention. Captivating visuals are much better than text and one way to do this is the use of realistic photography as visual content to promote the importance of recycling. This is because realistic photography is found to have better user engagement [25].

Minimalist and simple information design which entails good information arrangement is also appealing to the respondents. According to [26] content with strong underlying tones or confusing ones [27] might have negative effects on the information perception hence hindering intentions to share the contents. Digital information designers should use muted colours to create aesthetically pleasing design yet highlight necessary information. The use of heavy but simple fonts [28] can balance out the overall design of the digital information and still able to effectively deliver an appropriate amount of message. Respondents emphasised the use of proper hashtags as it is an important medium to reach the audience. The use of hashtags is a great way of building community online as it encourages audience to engage with the brand and attract them to the page [29][30]. From our observation of both Instagram accounts, most of the posts do not have hashtags which may attribute to user comments on the use of hashtags.

It must be reiterated that the respondents also prefer 'animated posts' post-type but such content is not posted by the account owners regularly. In fact, there was only 1 such post-type throughout our 4 months observation of which ironically, both accounts exude similar behaviour. This may imply that digital information design should consider animation as means of conveying information [31] as such information type are also sought after by users [32]. However, more data is required to validate this interpretation.

\section{Conclusion}

Our study has identified two Instagram accounts associated with environmental awareness particularly on recycling programmes. The results and discussion have helped us understand user perception towards social media digital information design and how the design might be improved for better user reception. We have found that to make a digital information design favourable, designers must consider user post-type preference and information elements available within the post.

This paper attempted to build a foundation of favourable user perception using 'Likes' as a variable which was then further probed with qualitative analysis of user interview. However, the respondent sample is small and did not represent users from abroad. This may present some limitation to the understanding of user perception towards information design. Additionally, we only observed two Instagram accounts for a short time duration. Lastly, the topic focus for our study is recycling and therefore our findings may not be generalizable to all forms of digital information design. This is because different information intention would have different target audience and different reaction expectation which would call for different digital information design strategy. Further studies could be undertaken to address the afore-mentioned limitation as well as build a better understanding on information design strategies to different type of information.

\section{Acknowledgements}

The authors would like to express the gratitude to the Ministry of Higher Education, Malaysia and Universiti Teknologi MARA, Selangor, Malaysia for the financial support given for this project (BESTARI Grant) [600IRMI/PERDANA 5/3 BESTARI (095/2018)].

\section{References}

1. R Newman, V Chang, RJ Walters andGB Wills. Web 2.0 - The past and the future. International Journal of Information Management.2016; 36, 4, 591-598.

2. S Greenwood, A Perrin and M Duggan. Social media update 2016. Pew Research Center. 2016; 11, 2.

3. J Wilkinson. Accessible, dynamic web content using Instagram. Information Technology and Libraries. 2018; 37, 1, 19-26.

4. NFA Agung and GS Darma. Opportunities and Challenges of Instagram Algorithm in Improving Competitive Advantage. International Journal of Innovative Science and Research Technology. 2019; 4, 1, 743-747.

5. A Prestin and KE Pearce. We care a lot: Formative research for a social marketing campaign to promote school-based recycling. Resources, conservation and recycling. 2010; 54, 11, 1017-1026.

6. O Heidrich andJ Harvey. An examination into recycling and waste management attitudes and behaviors by UK employees. Environmental Engineering and Management Journal. 2018.

7. K Stoeva, S Alriksson. Influence of recycling programmes on waste separation behaviour. Waste Management. 2017; 68, 732-741. 
8. Low awareness on recycling among Malaysians. The Star Online. Retrieved fromhttps://www.thestar.com.my/news/nation/2017/08/20/low-awareness-on-recycling-amongmalaysians, accessed August 2017.

9. KA Bakar. Solid Waste Management Lab 2015 Final Lab Report Malaysia: National Solid Waste Department,Ministry of Urban Wellbeing, Housing and Local Government.2015.

10. B Humă, E Stokoe andRO Sikveland. Putting persuasion (back) in its interactional context. Qualitative Research in Psychology. 2020; 17, 3, 357-371.

11. JA Mutang, R Ismail, CB Seok, F Bahari, L Madlan,W Wider andR Das. Recycling Motivations and Barriers in Kota Kinabalu, Malaysia. International Journal of Psychological and Behavioral Sciences. 2015; 9, 8, 2911-2915.

12. A Osman, F Md Isa, SN Othman and M Jaganathan. Attitude towards recycling among business undergraduate students in Malaysia. American-Eurasian Journal of Sustainable Agriculture. 2014; 8, 13, 6-12.

13. M Banga. Household knowledge, attitudes and practices in solid waste segregation and recycling: the case of urban Kampala.Zambia Social Science Journal. 2011; 2, 1, 4.

14. D Smeesters, L Warlop, G Cornelissen and P Vanden Abeele. Consumer motivation to recycle when recycling is mandatory: Two exploratory studies. Tijdschrift voor Economie en Management (3). 2003; 451-468.

15. RB Shehu, HB Shehu and R El Khatib. Green Networking a Way to Increase Recycling Awareness. Environmental management and sustainable development. 2018; 7, 2, 75-85.

16. MJ Albers. Human-information interaction with complex information for decision-making. Multidisciplinary Digital Publishing Institute.In Informatics. 2015;2, 2, 4-19).

17. A Dobele, D Toleman andM Beverland. Controlled infection! Spreading the brand message through viral marketing. Business Horizons. 2005; 48, 2, 143-149.

18. S Teng, KW Khong andWW Goh. Conceptualizing persuasive messages using ELM in social media. Journal of Internet Commerce. 2014; 13, 1, 65-87.

19. M Mormont andC Dasnoy. Source strategies and the mediatization of climate change. Media, Culture \& Society. 1995; 17, 1, 49-64.

20. AF Harun, SNA Adzman, FM Saman andSI Suliman. Architecting Virality: Information Sharing from Government FB Page to Netizens. Indonesian Journal of Electrical Engineering and Computer Science. 2018; 9, 3, 660-666.

21. EH Gebre andJL Polman. Developing young adults' representational competence through infographicbased science news reporting. International Journal of Science Education. 2016; 38, 18, 2667-2687.

22. Y Hu, L Manikonda andS Kambhampati. What we instagram: A first analysis of instagram photo content and user types. In ICWSM. 2014.

23. Y Ariel and R Avidar. Information, interactivity, and social media. Atlantic Journal of Communication. 2015; 23, 1, 19-30.

24. V Grigaliūnaitè and L Pilelienè. Making Brand Visible: Advertising Elements Influencing Visual Attention to the Brand. Journal of Emerging Trends in Marketing and Management.2016; 1, 1, 80-89.

25. E Lee, JALee, JH Moon andY Sung. Pictures speak louder than words: Motivations for using Instagram. Cyberpsychology, behavior, and social networking. 2015;18, 9, 552-556.

26. T Reichstein and I Brusch. The decision-making process in viral marketing-A review and suggestions for further research. Psychology \& Marketing.2019; 36, 11, 1062-1081.

27. Y Liang, W Liu, KK Liu and H Ma. Automatic generation of textual advertisement for video advertising. In 2018 IEEE Fourth International Conference on Multimedia Big Data (BigMM). 2018; 1-5.

28. L Prøitz. Visual social media and affectivity: The impact of the image of Alan Kurdi and young people's response to the refugee crisis in Oslo and Sheffield. Information, Communication \& Society. 2018; 21, 4, 548-563.

29. A Stathopoulou,L Borel, G Christodoulides andD West. Consumer branded\# hashtag engagement: can creativity in TV advertising influence hashtag engagement? Psychology \& Marketing. 2017; 34, 4, 448462.

30. Z Ye, NH Hashim, F Baghirov andJ Murphy. Gender differences in Instagram hashtag use. Journal of Hospitality Marketing \& Management. 2018; 27, 4, 386-404.

31. M Kergoat, T Meyer and A Merot. Picture-based persuasion in advertising: the impact of attractive pictures on verbal ad's content. Journal of Consumer Marketing. 2017.

32. A. Nikolinakou andKW King. Viral video ads: Examining motivation triggers to sharing. Journal of Current Issues \& Research in Advertising. 2018; 39, 2, 120-139. 